\section{Views of Prospective Chemistry Teachers on the Use of Graphic Organizers Supported with Interactive PowerPoint Presentation Technology in Teaching Electrochemistry Concepts}

\author{
Canan Nakiboğlu iD \\ Balıkesir University, Turkey
}

canan@balikesir.edu.tr

Nuri Nakiboğlu

Balıkesir University, Turkey

nnuri@balikesir.edu.tr

\section{Abstract}

The purpose of this study is to evaluate the views and experiences of the prospective chemistry teachers (PCTs) about the use of graphic organizers (GOs) supported with interactive PowerPoint presentation technology in teaching electrochemistry concepts. Ten GOs were developed and a pair of slides for all of them which contains partial and complete versions of the GOs was constructed. Participants of this study consisted of two different study groups. The preliminary trial of the study was carried out with four senior PCTs who have previously taken both an Electrochemistry course and an elective course concerning graphic organizers. Data from the first group of the study were collected by semi-structured interview and the experiences of the first group regarding the difficulties experienced during traditional electrochemistry teaching (didactic lecture) were examined. The second study group was eight PCTs who were in the fifth semester and were taking the Electrochemistry course while the study was being undertaken. In the las three weeks of the Electrochemistry course in the second study group, the course was taught with GOs supported with interactive PowerPoint presentation technology, and then the views of them were taken by a written opinion form. At the end of the study, three themes emerged regarding the experiences of the PCTs for the traditionally taught electrochemistry course. These are "difficulties", "inadequacy", and "not being beneficial". It was also concluded that the PCTs thought that the use of GOs supported with interactive PowerPoint presentation technology in teaching electrochemistry could enhance the comprehension and motivation of students.

\section{Keywords}

Electrochemistry teaching, graphic organizers, interactive PowerPoint presentation technology, prospective chemistry teachers

- Received 29 May 2020 • Revised 28 November 2021 • Accepted 17 December 2021
State of the literature

- No studies exist about the experience of the prospective chemistry teachers while they take the Electrochemistry course supported by interactive PowerPoint presentation technology in teaching electrochemistry concepts and about their views concerning the instructional approach applied.

- The exist an abundance of evidence in the literature that students perceive electrochemistry concepts as challenging and that both secondary school and university chemistry students have misconceptions of electrochemistry concepts.

- The concepts of electrochemistry include declarative knowledge, procedural knowledge, relational knowledge, and problem-solving which can each contain low or high levels of cognitive complexity. It is important to employ graphic organizers in the teaching of electrochemistry concepts to help students better understand abstract and problematic electrochemistry concepts.

Contribution of this paper to the literature

- This study can be provided an insight into the effects of electrochemistry teaching with GOs supported with interactive PowerPoint presentation technology on learners' comprehension and motivation and how to remedy learning difficulties concerning concepts.

- The GOs can also be used to increase students' participation in online classes and motivate them. In this perspective, the conclusion and the discussion of the study may guide today's online chemistry instruction and both pre-service chemistry teacher education and professional development of the chemistry teachers.

\section{Introduction}

Research has indicated that students at all levels have difficulty understanding chemistry concepts and have misconceptions about them (Butts \& Smith, 1997; Lu \& Bi, 2016; Nakhleh, 1992; Nakiboğlu, 2003; Nakiboğlu, 2008; Nakiboğlu \& Nakiboğlu, 2019; Nyachwaya et al., 2011; Taber, 1994; Taber et al., 2012). There are many reasons for the difficulties and misconceptions in chemistry. One of these reasons is related to the abstract nature of the chemistry concepts. The chemistry explanations include the invisible interactions between invisible entities. Another significant point can be related to the teaching approaches followed in the classroom during concept teaching since concept acquisition is a crucial facet of knowledge development (Fitzgerald et al., 2017). The chemistry concepts are generally presented by defining them using an expository way at the beginning of the chemistry lessons. During lessons, it is not overemphasized mostly whether the students can connect the relationship between the concept taught and previously taught concepts, or how to relate the previous knowledge to the newly taught subject. Furthermore, at the end of the course or during lessons, students achievement is usually assessed by the ability to solve algorithmic questions (Nyachwaya et al., 2014; Nurrenbern \& Pickering, 1987; Phelps, 1996; Pickering, 1990) by ignoring how the students build the relationship between the concepts of the subject in this evaluation process is not considered mostly. On the other hand, using formulas to solve algorithmic questions that demand only successfully using memorized procedures without the production of conceptual understanding is not a sign that the students have learned concepts and topics meaningfully and developing of 
students' high-order cognitive skills (Habiddin \& Page, 2021; Nakiboğlu \& Yıldırır, 2011; Nurrenbern \& Pickering, 1987; Papaphotis \& Tsaparlis, 2008).

The most critical point in the meaningful learning of a subject is whether the student has grasped the concepts in the subject correctly and has appropriately associated the concepts with each other. When teachers teach the subject matter and concepts in a manner that is clear and organized way, most of the students might learn much more meaningfully and remember the concepts for a longer time by connecting the concepts. At this point, the use of graphic organizers (GOs) in teaching chemistry topics can assist make expository texts more understandable for the students (Gil-Garcia \& Villegas, 2003). Ellies and Howard (2007) have defined GOs as "they are visual devices that depict information in various ways. The integration of visual devices into the lessons to build learning can lead students into producing conceptual constructions concerning topics taught. It can be said that based on the aforementioned explanations, GOs can facilitate learning in content areas of chemistry by providing clear visualizations of topics.

\section{Theoretical Framework}

The origin of the GOs is based on the cognitive theories of learning (Virk \& Wik, 2011). The cognitive approach examines to understand how incoming information is processed and structured into memory (Weinstein \& Mayer, 1986). Stating that there is an assumption among cognitive theorists that mental processes operate in an organized, predictable manner, Virk and Wik (2011) stated that including the use of GOs in the learning process will increase the functionality of these processes and improve memory retention and retrieval. Stahl's Depth of Processing model (Stahl, 1986) defines three broad levels of processing requirements regarding the cognitive demands which might be useful in planning instruction. These are association, comprehension, and generation. Association processing refers to a student who learns an association between a word/concept and its definition, or with a particular context (Stahl, 1986, p. 664). Comprehension processing involves having a student do something to demonstrate comprehension of an association. The process of a generation is where students use their knowledge to explain the meaning of a word in more abstract terms by generating a novel context. Incorporating the use of GOs during the learning process can enhance the functionality of these processes and improve memory retention and recall the information easily (Virk \& Wik, 2011). Furthermore, Wills and Ellis (2008) indicated that schema theory, dual coding theory, and cognitive load theory provide the basis for explaining the characteristics of GOs that support the learning process. In addition to these, Virk and Wik (2011) also expressed that subsumption theory/meaningful learning theory and information process theory can help us to understand how the GOs contribute to learning.

According to Ausubel's Meaningful Learning Theory, learning occurs when new material is related to relevant ideas that are already present in the existing cognitive structure (Ausubel, 1963 cited in Virk \& Wik (2011). For the acquisition of meaningful learning, the newly learned concepts need to be connected hierarchically to the learner's mind through the concepts learned in the previous lessons. The GOs can facilitate this process by providing students with a framework for relating existing knowledge to the new information learned (Virk \& Wik, 2011). Dye (2000) stated that "the graphic organizer has its roots in schema theory" (p.1). According to schema theory, ideas or concepts are related to one another in terms of a hierarchy of abstractness (Frayer et al., 1969). Knowledge is hierarchically organized and that teaching students relationships between and among their prior knowledge and new concepts will help students learn these new concepts and instantiate them into their cognitive structures. The use of GOs provides the learners to insert new knowledge into their existing schema (Virk \& Wik, 2011).

Information process theory is another learning theory that provides the basis for explaining the characteristics of the GOs. This theory focuses on aspects of memory encoding and retrieval. There are many versions of an information processing model formulated by several researchers and one of them was used by Johnstone (1997). According to the model, successful learning requires an efficient perception filter, working memory, and long-term memory. Dye (2000) explained the information processing process as follows. When the student comes across information, all this information enters the sensory register and is held there for only a few seconds in this process. If the student chooses to process the information, it then moves from the sensory register to short-term memory. At this point, the longer a piece of information remains in short-term memory, this information will move from short-term memory to longterm memory. Semantic memory is one of the parts of long-term memory. Semantic memory stores facts and general information in networks of connected ideas or relationships. Schema theory explains this integration even further. Weinstein and Mayer (1986) have shown the relationship between the GOs and how information is processed through short-term memory and long-term memory.

Although meaningful learning requires the student to participate in cognitive processing significantly during learning, the student's cognitive processing capacity is severely limited (Mayer \& Moreno, 2003). According to Chandler and Sweller (1991), "cognitive load theory suggests that effective instructional material facilitates learning by directing cognitive resources toward activities that are relevant to learning rather than toward preliminaries to learning. (p.293)". In this respect, the GOs can have positive effects on learning by reducing the cognitive load (Kwon et al., 2018; Stull \& Mayer 2007).

Based on all these explanations, it can be said that it may be helpful to include the GOs in teaching can help the information be actively used and processed. So, the use of GOs can be beneficial to enable students to construct the chemistry concepts and subjects meaningfully in their minds, to prevent the students from having misconceptions, and to assign students to take responsibility for their learning. The researchers who studied the effectiveness of using GOs during lessons have shown that using different types of GOs can enhance students' understanding of the content 
(Alvermann \& Boothby, 1986; Horton et al., 1990; Kwon et al., 2018). Besides, since concept learning, reasoning and conceptual problem-solving process contain internal cognitive processes, is difficult to measure internal representations of knowledge about concepts learned directly. At this point, the GOs can also serve as a beneficial measurement and evaluation tool.

\section{The Rationale and Research Questions of the Study}

The studies have shown that electrochemistry concepts are perceived as challenging by students and that both secondary school and university chemistry students have misconceptions of the concepts of electrochemistry (Allsop \& George, 1982; Brandriet \& Bretz, 2014; De Jong \&Treagust, 2003; Garnet \& Treagust, 1992a and 1992b; Lu \& Bi, 2016; Nakiboğlu \& Nakiboğlu, 2017a and 2017b; Nakiboğu \& Nakiboğlu, 2018, Ogude \& Bradley, 1994 and 1996; Özkaya, 2002; Rahayu et al., 2011; Rahayu et al., 2021; Serger \& Greenbowe, 1997a and 1997b). The problem underlying the learning difficulties concerning the concepts of electrochemistry includes all the issues addressed at the beginning of the introduction concerning chemistry learning difficulties in general. To summarize, electrochemistry is complex and consists of many abstract concepts. Besides the abstract nature of electrochemistry, the students are expected to connect electrochemistry concepts and principles with real-world applications. In addition to all these, there are algorithmic questions in the context of electrochemistry that are solved with the use of formulas and mathematical equations. Hence, it can be said that the concepts of electrochemistry include declarative knowledge, procedural knowledge, relational knowledge, and problem-solving which can each contain low or high levels of cognitive complexity. Therefore, the structuring of the concepts of electrochemistry in the minds of students requires them to establish macroscopic, microscopic, and symbolic relations. It is important to employ the GOs in the teaching of electrochemistry concepts to help students better understand abstract and problematic electrochemistry concepts, to construct the concepts in a meaningful way in their cognitive structure, and to lighten the cognitive load.

The usage of GOs has been reported in the literature for over 50 years. Torres, España, and Orleans, (2014) have noted that GO appears to be gaining popularity among modern schools today, as it has become a popular teaching approach and an accepted strategy in the classroom. When the studies conducted with GOs are examined, it is seen that a significant part of the studies focuses on examining the effect of using GOs in teaching in different fields on student learning. While in a few studies, only views about the use of GOs in the instruction were taken (Gil-Garcia $\&$ Villegas, 2003), in the other studies both the effect of GOs on the students' conceptual understanding levels were examined and the views were taken (Cala, 2019). But, it is seen that the number of studies focusing on the perceptions of teachers in different subjects and the use of GOs in their lessons is not very large. Most of the studies related to instruction have shown that the GOs facilitated significant improvements in students' conceptual understanding or students' higher levels of cognitive engagement (Cala, 2019; Kwon et al., 2018; Robinson et al., 2006). GilGarcia and Villegas (2003) asked several questions about GOs to faculty members, graduate, and undergraduate students. They found that students recognized the connection with prior knowledge and usefulness as a teaching strategy. The GOs can also be used to increase students' participation in online classes and motivate them. Kwon et al. (2018) have investigated the effects of GOs in online discussions and their major findings revealed that both generating and receiving the GOs facilitated students' higher levels of cognitive engagement, and encouraged students to consider alternative views during the discussions.

When the studies related to GOs were examined, it is seen that the effects of the use of different types of GOs in the teaching of chemistry subjects on student success and the opinions of the students participating in the teaching about the use of GOs were investigated (Cofer, 2021; Ezzeldin, 2017; Foley \& O'Donnell, 2002; Kummari, 2017; Maziadi, 2018; Phillips, 1989; Raymond et al., 2001; Torres et al., 2014). In these studies, it was determined that when chemistry subjects were taught using GOs, students' academic success increased and their attitudes towards chemistry lessons increased. For example, Torres, España, and Orleans, (2014) have conducted a study concerning facilitating a learning environment with the integration of graphic organizers (GOs) as a learning tool on selected topics in chemistry. At the end of the courses conducted by integrating GOs into the teaching of chemistry subjects, they concluded that the students' attitudes towards chemistry improved, they had a good perception of GO and their academic performance improved. In a different study, Maziadi (2018) determined that the students in the study showed a better understanding of chemistry when using a graphics organizer method instead of lecturing and students preferred the graphic organizer method in chemistry teaching. In addition to the studies in which chemistry teaching is carried out by using different GOs together, it is seen that there are studies in which teaching is carried out with a single GO type in the teaching of chemistry subjects and such studies are relatively more common. While it is seen that concept maps are the most used GO types in such studies (Aguiara \& Correia, 2016; Ghirardi et al., 2014; Moyses, Rivet, \&. Fahlman, 2010; Nakiboğlu \& Ertem, 2010; Polancos, 2013; Singh \& Moono, 2015), mind map (Ezeh \& Okeke, 2018; Nyagblormase et al., 2021), Vee diagram (Chamizo, 2012; Nakiboğlu \& Nakiboğlu, 2016, Nakiboğlu \& Nakiboğlu, 2017c; Polancos, 2013), flow diagram (Davidowitz, B \& Rollnick, 2001; Nakiboğlu et al., 2016; Nakiboğlu et al., 2017; Nakiboğlu et al., 2018), decision map (DeMeo, 2007) are the other GO types used. In many of these studies, the effect of the graphic organizer on student achievement was examined, while in some of them, students' views were taken.

No study has been found in which the experiences and opinions regarding both how to use different types of GOs in electrochemistry teaching and the use of GOs in electrochemistry teaching have been examined. In addition, as can be seen from the literature review, the teaching of electrochemistry concepts and subjects includes many problems. For this reason, not traditionally conducting the lessons with the use of different learning aids and interactively by the students may not be a solution to such problems of the students in the teaching of electrochemistry. For this reason, it is significant to learn the experiences and thoughts of the 
learners for such traditional approaches. Secondly, it is also critical to explore what they think about the use of GOs supported by interactive PowerPoint presentation technology in teaching electrochemistry concepts and whether the difficulties they experience in traditional learning can be overcome with this type of teaching. Thus, the present study has the potential to assist professionals in better understanding how can assist the PCTs meaningful learning about the utilization of GOs in electrochemistry teaching and their satisfaction. From this starting point, the research questions this study attempted to answer are the following:

1. What is the learning experience of the PCTs in the first group while they take the Electrochemistry course without support by interactive PowerPoint presentation technology in teaching electrochemistry concepts?

2. What are the views of the PCTs in the first group about the use of GOs supported by interactive PowerPoint presentation technology in teaching electrochemistry concepts after explaining how they use for teaching?

3. What are the views and the learning experience of the PCTs in the second group who attended the courses in which electrochemistry lessons are taught using the GOs supported by interactive PowerPoint presentation technology about the instructional approach applied?

\section{Method}

\section{The Participants and Context of the Study}

The phenomenological method was used in the present study. The phenomenological study describes the meaning for several individuals of their lived experiences of a concept or a phenomenon (Creswell ). The concept of "phenomenon", which is at the core of the phenomenological study, refers to everything experienced in life. What is experienced in this study is the teaching of electrochemistry and the focus of the study and the nature of the research questions were decisive in the selection of the phenomenology design. Phenomenologists focus on describing what all participants have in common as they experience a phenomenon (Creswell, 2007). Moustakas (1994) stated that while deriving scientific evidence in phenomenological research, the researcher establishes and follows a set of methods and procedures that meet the requirements of an organized, disciplined, and systematic study. The first two are to discover an important issue and question and to conduct a comprehensive review of the research literature. Therefore, the starting point of this study was the second author's expertise in electrochemistry and his experiences with learning difficulties in teaching electrochemistry subjects. Reviewing the literature in the study revealed the problems experienced in electrochemistry teaching in detail (this is also seen in Table 1). For this reason, the approach in the planning of the study is to develop learning aids to reveal the problems and solve the problems arising from the teaching by benefiting from the experiences of the people who took the electrochemistry course. It is also to enable PCTs to experience the learning tools developed later and to gain knowledge at this point.
A purposeful convenience sampling method (Patton, 2002) was used and the participants were drawn from the Chemistry Education Department at the Education Faculty of a Turkish Public University. The Chemistry Education Department has a 4-year pre-service teacher training program and its purpose is to educate teacher candidates for chemistry teaching in high schools. Before the implementation of this study, the researcher obtained permission from Ballkesir University's Internal Review Board (IRB) and Dean Office of the Education Faculty. At the beginning of the study, the participants in the study were informed about the purpose of the study, how the data was to be used within the project and that their participation was voluntary. Participants of this study consisted of two different study groups. All PCTs ranged in ages between 21 and 23 years.

The first study group was four PCTs in the eighth semester at the university. They took an Electrochemistry Course (a compulsory course) in the fifth semester of their third year and the Graphic Organizers course (an elective course) in the third semester of their second year. While the first group was taking the electrochemistry course, no intervention was made by the authors. From the previous examination, it was determined that this course was carried out according to the traditional method and by following the presentation strategy. A phenomenological study seeks not to evaluate each individual's experience for a phenomenon individually, but to understand the parts of these experiences that are common to humans in general (Johnson \&Christen, 2004). Thus firstly, it was tried to reach common experiences points of the first study group of PCTs, who had experienced traditional electrochemistry teaching without the use of any GOs. Besides, GOs prepared for use in electrochemistry teaching were shown to the first study group during the interview, and how they would be used in the electrochemistry course was explained and later it was tried to determine what this group thought in the case of the GOs supported with interactive PowerPoint presentation technology in the teaching electrochemistry.

The second study group was included in the study after the data obtained from the first study group were analyzed. They were eight PCTs who were in the fifth semester and were taking the Electrochemistry course while the study was being undertaken. As will be explained in detail in "the data collection from the second group" section with these PCTs, the electrochemistry course was taught with the GOs supported with interactive PowerPoint presentation technology, and then the thoughts of them were received. Thus, the second study group was enabled to experience teaching electrochemistry with the GOs supported with interactive PowerPoint presentation technology.

\section{Data Collection}

\section{Preparation of the GOs}

A total of 10 GOs which were three Concept Definition Maps, one Semantic Feature Analysis, two Flow Charts, one Comparison-contrast Matrix, one Spider Map, and two Positive, Negative, and Interesting Diagrams were developed for the electrochemistry concepts and topics of 
thought. A pair of slides for all GOs which contain partial and complete versions of the GOs was constructed. Partially completed GOs were used to guide the students through the information in each GO. In the process of constructing the GOs, firstly the concepts to be taught were selected while taking into account some circumstances. In this decision-making process, priority was given to the concepts that students had misconceptions or had learning difficulties in the literature. After the concepts were chosen, the type of GO was decided according to the learning goal. All GOs constructed in this study and the challenges taken from literature about correlated concepts are shown in Table 1.

It is not appropriate to have a solid pattern for GO preparation, as different paths will be followed for each type of GO, or even for a type of GO, depending on the focus of the concept or subject. In addition, different ways can be followed in teaching according to the GO type and concept, while using an interactive way during the lesson, as it was done in this study, that is, by asking questions to the students during the filling, by brainstorming or by making a whole class discussion. Following is the explanation of all the GO types prepared in the study and for which topic/concept and for what purpose they were prepared. In addition, three of the GOs prepared in the study were selected as examples (Figure 1, 2, 3) and explained in detail below in order to better illustrate the ways followed during the preparation of GOs and their use in electrochemistry teaching.

The concept definition map developed by Schwartz and Raphael (1985) is a visual representation of a definition. Based on attempts by cognitive psychologists to describe the structure of semantic knowledge, a concept definition map provides a framework for organizing conceptual information in terms of three types of relationships: categories, properties, and examples of the concept. As a strategy, it emphasizes the importance of students being able to figure out new concepts on their own, instructs them in what types of information make up a definition, and teaches them how to use context clues and background knowledge to increase their understanding of concepts (Schwartz and Raphael, 1985; Schwartz, 1988). Learning a concept requires having two types of knowledge about the concept. These are definitional knowledge and contextual knowledge. Definitional knowledge can be defined as the knowledge of the relations (synonymic, superordinate, subordinate, etc.) between a word and other known words, as in a dictionary definition. Contextual knowledge can be defined as knowledge of a core concept and how that concept is realized in different contexts since the meanings of words can change in different contexts (Stahl, 1985). Concept definition map can provide to elicit both students' definitional knowledge and contextual knowledge and also provides a means to see students' misconceptions.
Table 1. The GOs constructed and the challenges about correlated concepts

\begin{tabular}{|c|c|c|}
\hline $\begin{array}{l}\text { Type of } \\
\text { GO }\end{array}$ & Concept & Misconceptions/Problems about Concept \\
\hline \multirow{3}{*}{ 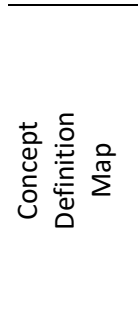 } & Salt bridge & $\begin{array}{l}\text { The salt bridge supplies electrons to complete the circuit (Garnett \& Treagust, } \\
\text { 1992b). } \\
\text { The salt bridge assists the flow of current (electrons) because positive ions in the } \\
\text { bridge attract electrons from one half-cell to the other cell (Garnett \&Treagust, } \\
\text { 1992b). }\end{array}$ \\
\hline & $\begin{array}{l}\text { Redox } \\
\text { Reactions }\end{array}$ & $\begin{array}{l}\text { Oxidation and reduction processes can occur independently (Garnett \& Treagust, } \\
\text { 1992a) }\end{array}$ \\
\hline & & $\begin{array}{l}\text { The " }+ \text { " and the "-" ends of the batteries are charged, so the " }+ \text { " end of a battery } \\
\text { attracts electrons (Yang et al., 2004). }\end{array}$ \\
\hline 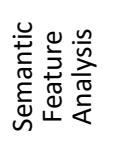 & $\begin{array}{r}\text { Oxida } \\
\text { Num }\end{array}$ & $\begin{array}{l}\text { The oxidation state of an element is the same as the charge of the monatomic ion } \\
\text { of that element. (Garnett \& Treagust, 1992a). } \\
\text { Oxidation numbers or states can be assigned to polyatomic molecules and/or } \\
\text { polyatomic ions (Garnett \&Treagust, 1992a). }\end{array}$ \\
\hline \multirow[b]{2}{*}{$\frac{\bar{d}}{\frac{\overline{0}}{n}} \stackrel{\frac{0}{\pi}}{\frac{\pi}{2}}$} & ic Cell & $\begin{array}{l}\text { In a cell, the anions and cations attract each o } \\
\text { of ions to the electrodes (Garnett \& Treagust }\end{array}$ \\
\hline & & $\begin{array}{l}\text { Electrons move through electrolytes by being attracted to positive ions in the } \\
\text { solution (Garnett \& Treagust, 1992a). } \\
\text { Electrons flow in electrolytes (Garnett \& Treagust, 1992a). } \\
\text { In galvanic cells, the anode is positively charged because it has lost electrons; the } \\
\text { cathode is negatively charged because it has gained electrons (Sanger \& } \\
\text { Greenbowe, 1999). }\end{array}$ \\
\hline \multirow[b]{2}{*}{ 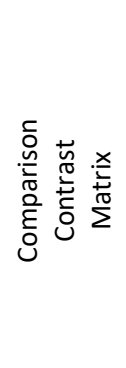 } & $\begin{array}{l}\text { Electrochemic } \\
\text { Cells }\end{array}$ & $\begin{array}{l}\text { is negatively charged and because of this, it attracts cations. The } \\
\text { positively charged and because of this, it attracts anions (Garnett \& } \\
\text { 1992b). }\end{array}$ \\
\hline & & $\begin{array}{l}\text { The anode is positively charged because it has lost electrons. The cathode is } \\
\text { negatively charged because it has gained electrons (Garnett \& Treagust, 1992b). } \\
\text { Processes at the anode and cathode are reversed in electrochemical and } \\
\text { electrolytic cells; in electrochemical cells oxidation occurs at the anode and } \\
\text { reduction at the cathode, while in electrolytic cells oxidation occurs at the } \\
\text { cathode and reduction at the anode (Garnett \& Treagust, 1992b; (Özkaya et al., } \\
\text { 2003). }\end{array}$ \\
\hline \multirow{2}{*}{ 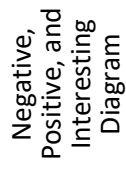 } & $\mathrm{D}$ & $\begin{array}{l}\text { Batteries are dead when all the electrons inside a battery are used up (Yang et } \\
\text { al., 2004). }\end{array}$ \\
\hline & $\mathrm{Ni}-\mathrm{Cd}$ Cell & $\begin{array}{l}\text { Batteries are dead when all the electrons inside a battery are used up (Yang et } \\
\text { al., 2004). }\end{array}$ \\
\hline \multirow{3}{*}{$\frac{3}{\frac{t}{\pi}}$} & & I Batteries are dead when all the electrons inside a battery are used up (Yang et \\
\hline & & \\
\hline & $\begin{array}{l}\text { sis of } \\
\text { ar }\end{array}$ & Problems with the definition of electrolysis (Kong, 2016). \\
\hline
\end{tabular}


In this study, three concept definition maps related to salt bridge, redox, and battery, which were determined to be misconceptions of students in the literature, were prepared. The reason why the number of concept definition maps is higher than other GO types in this study is that concept definition map focuses on concepts. Because these concepts are prerequisites for the topics of electrochemistry, the PCTs must first learn these fundamental concepts well and not have misconceptions on these concepts to learn electrochemistry meaningfully. While preparing the concept definition maps, first of all, the fundamental concepts of electrochemistry and whether there are any misconceptions and/or learning difficulties related to them were determined from the literature (Table 1). Then it was decided what should be placed around the main concept at the center taking into account the characteristics of the concept. For example, when the concept definition map for the salt bridge in Figure $\mathbf{1 b}$ is examined, it is seen that it consists of four parts. These are the definition of the main concept, features, or important points of the concept (this part may vary according to the concept chosen), misconceptions, and/or learning difficulties about the main concept, and examples. While preparing the concept definition map concerning the salt bridge, firstly the main concept, the salt bridge, was placed in the center of the concept definition map. While focusing on the definition of the main concept in the figure at the top of the main concept, the figure on the right of the main concept especially focused on the function of the salt bridge in electrochemical cells, since its function was confused by the students. The question of "what is it not like" in the left part of the main concept was especially preferred and it was aimed to draw the attention of the students to what the salt bridge is not. Because, as seen in Table 1, the most important problem about the salt bridge is that the students have a misconception about the salt bridge as "the salt bridge assists the flow of electrons". For this reason, with such a question, it was tried to prevent students from having such a misconception. Finally, at the bottom figure of the main concept, the salt samples used in the preparation of the salt bridge were asked.

The following way was traced when using the constructed concept definition map during the teaching period. Since the pre-service teachers learned some of these concepts at the high school level, the concept definition map was used to examine the prior knowledge while teaching the second group in this study. For this purpose, the slide in Figure 1a (the partially completed concept definition map) was presented to the PCTs, and the first question concerning the definition of the salt bridge was directed to the PCTs and discussed, and after concluding the whole class discussion, this definition was shown to the students on the slide. Similarly, other parts of the concept definition map were completed. In the use of the other two concept definition maps concerning redox and battery during the teaching process, a way similar to that of the salt bridge was followed. (a)

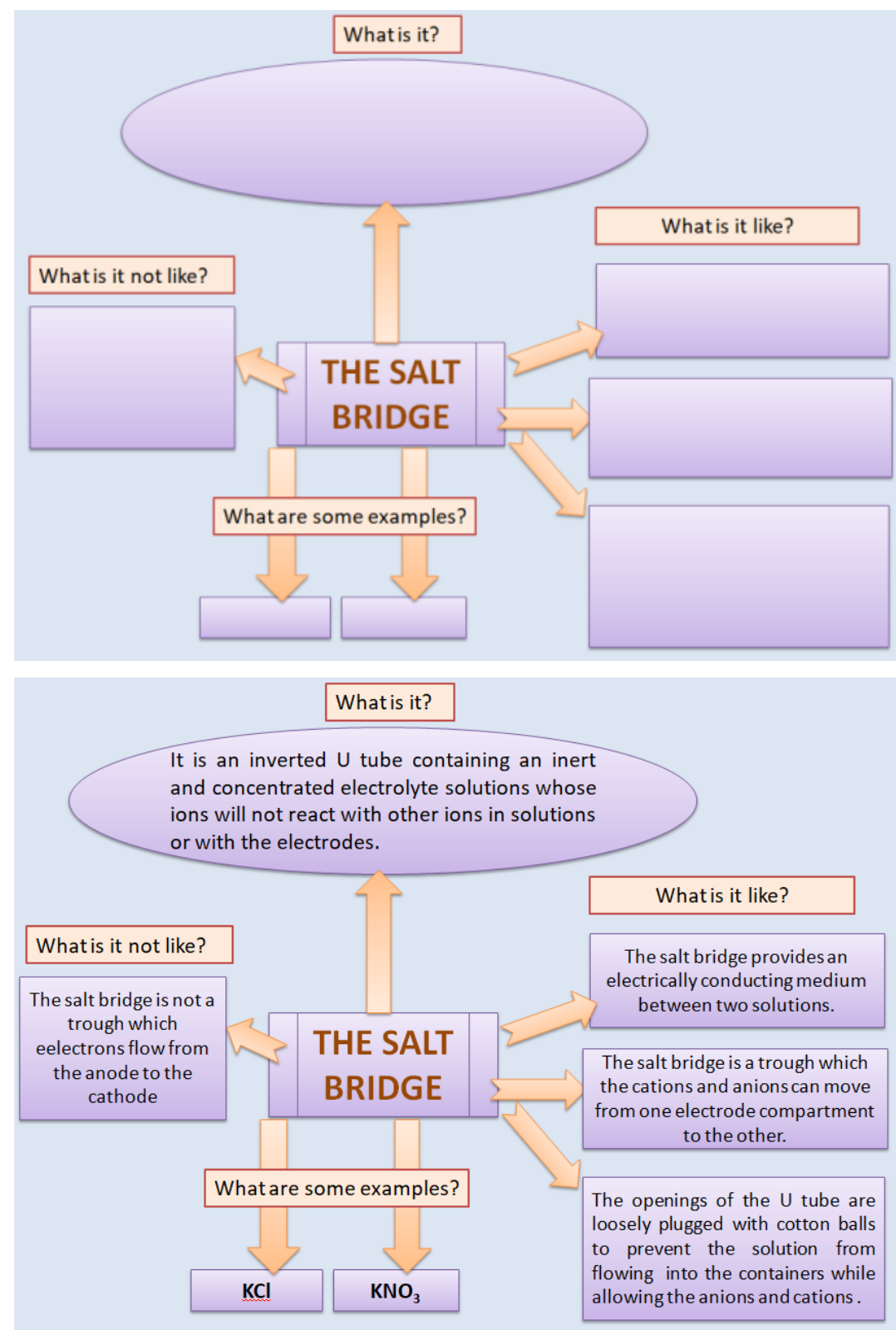

Figure 1. Examples of the partial (a) and completed (b) concept definition maps used in the study 
The semantic feature analysis (SFA) was defined as a strategy that can be used to teach both the vocabulary and the concepts needed for comprehension by Anders and Bos (1986). Anders and Bos (1986) have indicated that SFA differs from traditional content area vocabulary instruction since students interact with words that are functionally and conceptually related and differ in their degree of abstraction. Thus, SFA can enable students to learn the relationships between and among the conceptual vocabulary of science and the major ideas in the text. The semantic feature analysis strategy uses a relationship chart to help students explore how concepts are similar and different (Anders \& Bos, 1986). In this study. a semantic feature analysis was used to help the students understand and adapt oxidation numbers. By using this activity, students' procedural knowledge regarding oxidation numbers was elicited and they compared the oxidation numbers of different formulas, so build conceptual knowledge. The semantic feature analysis relation chart was prepared as a pair of slides that contains partial and complete versions of the chart. The semantic feature analysis relation chart is seen in Figure 2. The formulas of example compounds were listed down the left-hand column and the oxidation numbers were presented across the top row of the chart. After students were reflected this slide, they were asked to select a cell if the formulas aligned with an oxidation number and after whole-class discussion whether which answer was right to help students review key rules related to determining the oxidation numbers, a plus sign was placed in the cell on the screen.

The Spider Map is preferred if the topic at hand involved investigating attributes associated with a single topic and then obtaining more details on each of these ideas. McKnight (2010) indicates that the Spider Map is a free-form graphic organizer that allows students to think hard about information as both visual and metaphorical. Thus, the students can visualize the interconnectedness of information and ideas to a central idea. A spider map has a main idea or topic in the center, or the body, of the diagram. Each detail or sub-topic associated with the main idea has its leg, or branch, surrounding the main idea. The galvanic cell consists of different parts, and it has been indicated that the students can easily confuse their tasks of these parts with each other. Since seeing the parts of the galvanic cell and the function of each on a single slide can enable the student to engage in deep thinking, the galvanic cell was selected as the main topic for the spider map.

The following procedure was tracked in interactive filling of the spider map with the students during the lesson. Firstly, a partially filled version of the spider map in Figure $\mathbf{3}$ is reflected and the PCTs were asked the question of what parts of the galvanic battery consist of. In line with the answers from the students, the oval shapes in which the galvanic cell parts around the central concept would be written were filled with the students. Then, for each galvanic cell element, depending on the concept, questions such as what it is, what parts it consists of, what its function in the electrochemical battery is, were directed to the students. After the class discussion, the rectangular shapes seen in Figure 3 were filled in.

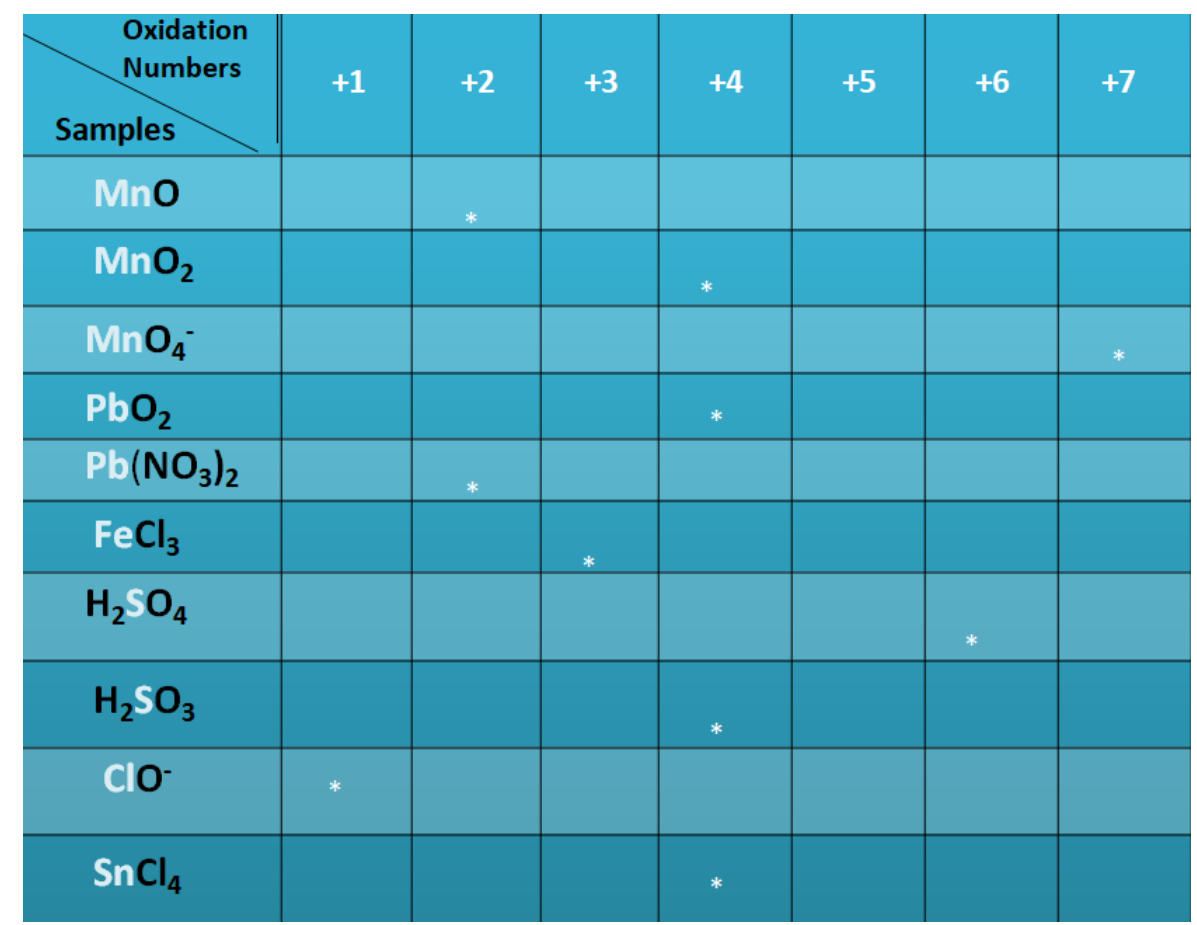

Figure 2. The semantic feature analysis

A Comparison-Contrast Matrix was favored, when it was aimed to enable students to see the similarities and differences of two distinct concepts that have common points that they easily confuse with each other. Studies have shown that students failed to differentiate between the galvanic and electrolytic cells (Amponsah, 2020). The galvanic and electrolytic cells and especially the signs of the anode and cathode are easily confused by the students in terms of whether the battery reaction occurs spontaneously or not. Besides, the fact that these two cells are explained in different parts in teaching and books does not allow them to compare the two cells with each other. In this study, a Comparison-Contrast matrix was constructed to show the similarities and differences of galvanic and electrolytic cells in detail on a single slide, considering that it will help to understand how two cells are both different and alike at the same time. 


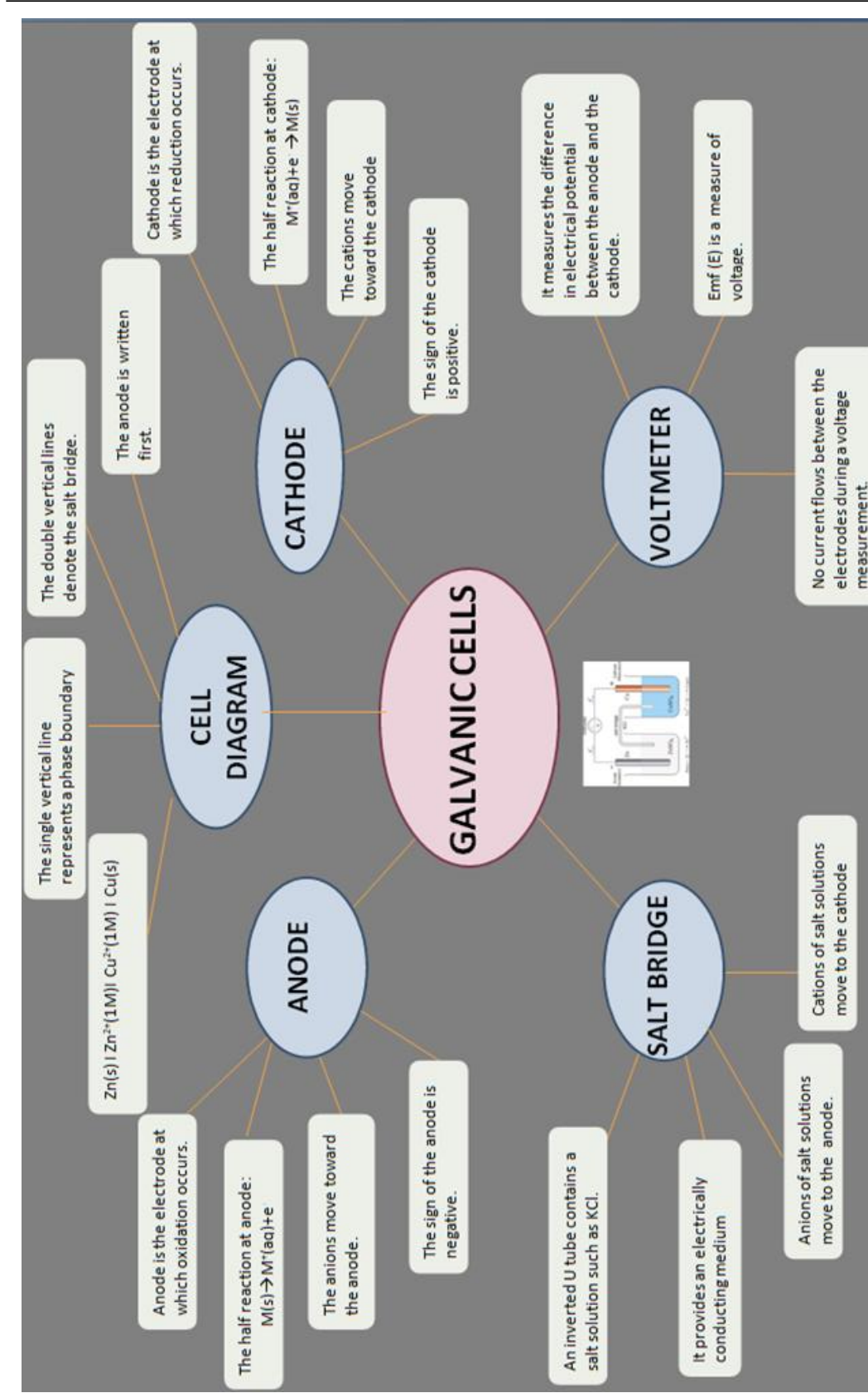

Since, a Positive, Negative and Interesting Diagram is an effective reflection tool to allow students to look at the whole picture of an event and also to help them see both sides of a concept and think more broadly about it, two Positive, Negative, and Interesting Diagrams concerning the Dry and Nickel Cadmium Cells were created. The Flow Charts were used in two different ways to show the process. The First Flow Chart regarding electrochemical cells was created to show the progress of ideas, thoughts, or steps. The second Flow Chart was related to an experiment titled the electrolysis of water and it was intended as a means of requiring students to process laboratory instructions before conducting experiments.

\section{Data collection from the first group}

Data were collected through the interview. The reason for collecting data from the first group was to help determine the questions to be included in a fully structured form for the second study group, and to reveal the learning experiences of pre-service teachers who took electrochemistry lessons without using any GOs. All of the interviews were conducted and recorded by the first author. Each PCT interview lasted 15-20 minutes. The way followed and the questions asked during the interview with the first group are as follows. The author made the following explanation verbally to all PCTs at the beginning of the interview.

"In the previous years, you took the Electrochemistry, the Conceptual Change and Misconception, and the Graphic Organizers courses. Within the scope of the Conceptual Change and Misconception course, you were explained and discussed both the learning difficulties and misconceptions related to the electrochemistry concepts. We have constructed diverse GOs supported by an interactive PowerPoint presentation for use in teaching electrochemistry concepts and preventing the formation of misconceptions. Now I will explain how to be used of the GOs in teaching interactively, showing each GO one by one. Later I would like to get your views on each GO”.

Three types of questions were used. The first set of questions is a similar question asked for each $\mathrm{GO}$, taking as an example how the question is posed for the concept definition map below. While asking this question, firstly the author showed all partial and completed GOs to the PCTs interviewed separately. After describing how to use GOs regarding each concept, the PCTs were asked what they think about the use of these GOs in the teaching of the concept presented. The concept definition map constructed for teaching the salt bridge is given below as an example to show how the first questions were directed to the PCTs for each GO pair.

"This is a Concept Definition Map which was constructed for teaching the salt bridge and consists of geometric shapes and links (arrows). As you can see, the main concept, the salt bridge was written into a geometric shape placed in the center of this map, and the blank geometric shapes and several questions 
subordinate to the main concepts were placed around the main concept (Figure $1 \mathrm{a})$. After this slide is shown to the students, these questions will be asked to the students and a complete format of this GO will be shown to the students after the whole class discussion (Figure 1b). Could you explain what you think about the use of these GOs in the teaching of the salt bridge?"

While PCTs were answering the first question, when they talked about a learning problem related to the electrochemistry concept or topic presented and touched on a different situation related to the use of GOs in teaching, or the meaning of the PCT's answer was not clearly understood, the specific questions as the second questions were asked. As an example of such probe questions, two sample questions directed to PT1 are given below. In addition, how these questions were used in PT1's interview and PT1's answers are shown in the findings section. Probe questions asked to other PTs when additional questions need to be asked are very similar to those asked to PTC1.

Were you able to understand this concept better if this kind of material was used?

Why did you have difficulty while taking an electrochemistry class?

What can you say if you compare this type of lecture with the lecture presenting information orally in a traditional way?

After completing the questions about their views concerning GOs and their experiences while taking electrochemistry courses, the following question was asked as the last question (the third type of question).

When you become a chemistry teacher in the future, do you plan to use such GOs in your courses? Why?

\section{Data collection from the second group}

Data were collected while eight PCTs in the second group were taking the Electrochemistry Course. After the course content was completed by the instructor of the course, the first author of this study carried out the rest of the lessons, for three weeks (six lessons), using the GOs supported by an interactive PowerPoint presentation. Instructional sessions were conducted during regular course lessons. Before starting the implementation, an electrochemistry conception diagnostic test was applied to the PCTs. After the administration, the answers to the test questions were discussed and the misconceptions and learning difficulties about electrochemistry concepts were explained.

In the following weeks, The PCTs were taught using the GOs supported by an interactive PowerPoint presentation on the electrochemistry concepts that are difficult to learn or students have misconceptions. During instruction, firstly a partial GO incorporated into the PowerPoint presentation was shown on the computer while the instructor verbally focused students' attention on the partial GO and drew them into the discussion by asking the questions related to information needed to complete the partial GO. The partial GO format guided students' thinking and allowed students to gradually construct the concepts and enhance rational knowledge. After a whole group discussion, the author presented the slide which contains the completed GO.

At the end of the instruction, the views of the PCTs and experiences about incorporating GOs into the teaching electrochemistry concepts were taken by using an instrument. The content validity of the instrument was provided by both the instructor of the Electrochemistry course and the authors' expert judgment. The questions of the instrument were linked with the objectives of the study logically which establishes the face validity (Kumar, 1999, p. 138) and also took into account the data obtained from the interviews of the first study group.

\section{Analysis and Presentation of Data}

The analysis of the data belonging to the two study groups was carried out separately because the reasons for inclusion in the study were slightly different from each other and the ways of collecting data were different. While the data obtained from the first study group were presented to answer the first two research questions, the data obtained from the second group were presented to answer the third research question. The data of the first group were presented with verbal explanations and sampled with quotations from the statements of the PCTs since the number of participants was small and almost all of them explained the experience similarly. Since the data obtained from the second group were suitable for tabulation, they were presented in two tables (Tables 2, 3) and a graphical representation showing the comparison and relationships of them was created (Figure 2).

The phenomenological psychological method was used to analyze the data (Isabirye \& Makoe, 2018). In the first step, the transcripts of the interviews were read several times to familiarize oneself with the data and this served as a basis for the second step. In the second step, the whole description was broken into its constituent parts. The process of delineating parts was referred to as identifying meaning units. In the third step, meaning units in clusters were regrouped to build a coherent structure of the meaning of the PCTS' experiences. In the fourth step, the meaning units were transformed into descriptive expressions. So, common themes were identified which reflect the general experience of the phenomenon by the participants and are conducive to generalization.

To obtain the inter-rater reliability of the analysis, the data were analyzed by the authors independently at first (the inter-rater reliability was 95\%), and all interpretation and coded data were checked by the authors together. Additionally, after validating the coding scheme, the first author independently coded all of the interviews at two different times and the intra-judge reliability was also provided by the first author (Gay \& Airasion, 2000, p. 175). 


\section{Findings}

\section{The Learning Experience of the PCTs in the First Group about the}

\section{Electrochemistry Course Taught in the Traditional Way}

From the analysis of interviews with the 4PCTs, three themes emerged regarding the experiences of the PCTs for the traditionally taught electrochemistry course: (1) Difficulties, (2) Inadequacy, (3) Not being beneficial. The important aspects of these themes are identified below.

The common point of 4 PCTs was that they all had difficulties while taking the Electrochemistry course. Even PCT2, one of the PCTs, who has the best academic achievement in her all courses, stated that she had difficulty with the Electrochemistry course. PCT4 said that she did not like the Electrochemistry course and did not even want to talk about electrochemistry at the beginning of the interview. When she was asked why she did not like the Electrochemistry course, she stated that she especially did not like the teaching style of the lecturer. When other PCTs were asked why they had difficulties in the Electrochemistry course, all of them cited the presentation of the course notes through slides in an expository way as the most important reason for their difficulty in understanding, as can be seen in the excerpts from PCT2 and PCT1 below:

I: What do you think was the reason for having difficulty while taking the Electrochemistry course?

PCT2: Actually, the topics were not difficult; I think the professor's expository teaching style was caused by it. Thus, I could not benefit enough from the lesson.

PCT1: ........I had a lot of difficulty with the Electrochemistry course.

I: What do you think was the reason for having difficulty while taking the Electrochemistry course?

PCT1: Topics were taught and passed quickly with the slide containing only the written notes. It was almost impossible to even take notes. Anode/cathode and calculations were emphasized. So many cells were shown that I don't even remember which one was showing right now. .....

PCT1: The galvanic cell is very confusing. What happens at the anode? What happens at the cathode? What is the reason for using the salt bridge in a galvanic cell? What are the elements of a galvanic cell? These questions occurred in my mind and I could not form the answers.
The Views of the PCTs in the First Group about the Use of GOs

Supported by Interactive PowerPoint Presentation Technology

As a result of the analysis of the PCTs' views about the use of GOs supported by interactive PowerPoint presentations, five themes emerged: beneficial, improving retention of information, providing better understand, drawing attraction, funny. It was determined that PCTs think that the use of GOs in the teaching of electrochemistry concepts would be beneficial. Especially after examining the GOs shown to PCT1, she stated that the difficulty she had previously experienced during their electrochemistry lesson would not have been possible if such a GO had been used. The sample excerpts were taken from the interview conducted with the PCT1 are given below.

I: Could you explain to me what you think about the use of this Concept Definition Map in the teaching of the salt bridge? (This was asked after explaining and showing how to use the slides in Figure 1 in teaching electrochemistry.)

PCT1: I think it would be beneficial. Because when we took the Electrochemistry course, the topics were explained to us with linear notes written on slides. The professor asked what a salt bridge is during her presentation. When she got a response from a student, she said "okay then" and continued her description. We did not see this issue like that. If we were to see it like this, it would improve the retention of information as we would see important information, what happened, and examples.

I: Please look at this slide. This is the second Concept Definition Map which is related to the concept of redox. Could you explain to me what you think about the use of this Concept Definition Map in the teaching of redox?

PCT1: It would be great. I suffered a lot from this. I was constantly mixing.

I: Were you able to understand this concept better if this kind of material was used?

PCT1: Yes, I would understand better. I think it attracts the attention of the student, because it is colorful, as well as giving important information, examples, and seeing all of them (all information) in one place. And it caught my attention right now.

I: What do you think about such a Semantic Feature Analysis is used to teach oxidation states? (Partial completed and completed slides are shown)

PCT1: It would be better to use this type of material rather than give them to the student to write them one by one. The student understands both what to find and checks direct options. It can determine and mark it directly. I think this is very logical, it would be much better to ask the student in a chart rather than give examples one by one. 
I: What would you think about using a Flow Chart to teach the difference in batteries?

Can it help the student understand the difference between batteries?

The Views and Experience of the PCTs in the Second Group who Attended the Courses in which Electrochemistry Lessons Taught Using the GOs Supported by Interactive PowerPoint Presentation Technology The PCTs' views and experiences on the effect of using GOs supported with an Interactive PowerPoint presentation have been collected under two subtitles: teaching electrochemistry concepts and misconceptions of electrochemistry. The PCTs' views on the effect of using GOs supported with an interactive PowerPoint presentation in teaching electrochemistry were grouped under the following two main themes: enhancing comprehension and enbancing motivation. The main themes and sub-themes are presented in Table 2 .

As can be seen from Table 2, the views of PCTs concerning the theme of "enhancing comprehension" were grouped into the following seven sub-themes: (1) understanding; (2) awareness; (3) retention; (4) efficiency; (5) useful; (6) facilitator; and (7) effective.

Almost all PCTs (7 of the 8 PCTs) thought that using GOs in the lessons enhanced students' understanding since it helped students understand the topic better, learn some concepts correctly, and can reinforce understanding. A representative example of the understanding theme which contains expressions concerning both better understanding and reinforcement is given below.

"Making comparisons or stating similarities between the two concepts helps us to understand those concepts better. By using these GOs at the end of the teaching, information can be reinforced (PCT7)."

While 4 of 8 PCTs thought that the use of GOs provided awareness, 3 of them indicated that they increased retention of the information. PCTs also stated that the use of GOs would remove the question in a student's mind (PCT7), prevent confusion (PCT11), and provide learning easily (PCT10). Two representative expressions of the themes "awareness" and "retention" are given below.

"Seeing the similarities and differences of the concepts on the same material provides more opportunity for us to distinguish them (PCT11)."

"Availability of visual material while teaching and due to visual memory, the information becomes catchy (PCT12).”
Table 2. The PCTs' views on the effect of using GOs supported with an interactive PowerPoint presentation technology in teaching

\begin{tabular}{|c|c|c|c|}
\hline Themes & Sub-Themes & Sample expression & Numbers of the PCTs \\
\hline \multirow{12}{*}{ 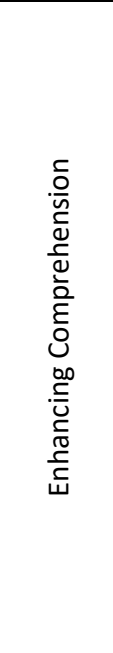 } & \multirow[t]{4}{*}{ Understanding } & The use of GOs helps students understand the & PCT5, РCT7, РCT8, \\
\hline & & topic better. & РСТ10, РСТ11 \\
\hline & & $\begin{array}{l}\text { The use of GOs helps to learn some concepts } \\
\text { correctly. }\end{array}$ & РСТ6, РСТ8, РСТ12 \\
\hline & & The use of GOs can reinforce understanding. & PCT7, PCT11 \\
\hline & \multirow[t]{2}{*}{ Awareness } & $\begin{array}{l}\text { The use of GOs allows the student to see the } \\
\text { knowledge in full and comparatively at the same } \\
\text { time. }\end{array}$ & РСТ6, РСТ7, РСТ11 \\
\hline & & The use of GOs provides seeing the differences. & РCT11 \\
\hline & Retention & $\begin{array}{l}\text { The use of GOs increases the retention of } \\
\text { information. }\end{array}$ & РСT6, РСТ9, РСТ12 \\
\hline & \multirow[t]{2}{*}{ Efficiency } & $\begin{array}{l}\text { The use of GOs can remove the question from a } \\
\text { student's mind. }\end{array}$ & PCT7 \\
\hline & & The use of GOs prevents confusion. & PCT11 \\
\hline & Useful & The use of GOs in lessons is very useful. & РСT6 \\
\hline & Facilitator & The use of GOs provides learning easy. & PCT10 \\
\hline & Effective & The use of GOs makes the lesson effective. & PCT6 \\
\hline \multirow{3}{*}{ 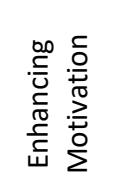 } & Attractive & GOs are attractive. & РСТ6, РСТ10, РСТ12 \\
\hline & Focuser & $\begin{array}{l}\text { The use of GOs makes it better to focus (on the } \\
\text { lesson). }\end{array}$ & РCT10 \\
\hline & Funny & The use of GOs makes the lesson fun. & РCT6 \\
\hline
\end{tabular}

Regarding the second main theme, 3 of 8 PCTs viewed the GOs as attractive material, focuser, and funny. For this reason, the second theme was coded as "enhancing motivation". Two representative expressions of these sub-themes are given below.

"The GOs explain the subject clearly and attractively, without long confusing expressions. (PCT12)."

"Since using visual materials rather than verbal lectures will be more interesting, the focus on the subject will be better and the subject will be more clearly understood. (PCT10).”

The findings of PCTs' views on the effect of using the GOs supported with an interactive PowerPoint presentation on misconceptions of electrochemistry are presented in Table 3. 
Table 3. The PCTs' views on the effect of using GOs supported with an interactive PowerPoint presentation technology on misconceptions of electrochemistry

\begin{tabular}{lll}
\hline \multicolumn{1}{c}{ Theme } & \multicolumn{1}{c}{ Sample expression } & Numbers of the PCTs \\
\hline $\begin{array}{l}\text { Overcoming of } \\
\text { misconception }\end{array}$ & $\begin{array}{l}\text { The use of GOs helps to overcome } \\
\text { misconceptions. }\end{array}$ & PCT7, PCT8, PCT10 \\
$\begin{array}{l}\text { Hindering of } \\
\text { misconception }\end{array}$ & $\begin{array}{l}\text { The use of GOs hinders the development of } \\
\text { misconceptions. }\end{array}$ & PCT6, PCT8, PCT12 \\
$\begin{array}{l}\text { The use of GOs allows misconceptions to be } \\
\text { misconception }\end{array}$ & $\begin{array}{l}\text { seen more clearly. } \\
\text { The use of GOs allows misconceptions to be } \\
\text { diagnosed. }\end{array}$ & PCT7 \\
$\begin{array}{l}\text { Reducing of } \\
\text { misconception }\end{array}$ & $\begin{array}{l}\text { Phe use of GOs helps to reduce } \\
\text { misconceptions. }\end{array}$ & PCT5, PCT9 \\
\hline
\end{tabular}

When Table 3 is examined, it is seen the PCTs' views about misconceptions of electrochemistry are grouped in the following four sets: (1) overcoming misconceptions; (2) hindering of misconceptions; (3) diagnosis of misconceptions; and (4) reducing misconceptions. It was found that some of the PCTs' views were included in both data sets, while some PCTs had only one thought. A representative expression of the PCTs regarding the data sets is given below.

"The use of GOs hinders the formation of misconceptions for the differences between electrolytic and Galvanic cells. Because the correctness of the concepts is clearly understood on the GOs as it describes similarities and differences in items. At the end of the lesson, if the student has a misconception, we can also see where he/she has a problem by looking at it (PCT12)."

During the analysis of explanations of the PCTs concerning misconceptions, it was determined that although they were not asked such a question, PCT6 and PCT7 also said they would use the GOs in their lessons when they were teachers in their future classes. An example expression is given below.

"It is a technique that I will use when I start my profession in the future. A teaching technique that increases the retention of information, prevents misconceptions, and attracts attention (PCT6)."

\section{Conclusions}

Two groups of PCTs with different experiences in teaching electrochemistry were involved in the present study. The study investigated firstly the learning experience of the PCTs in the first study group about the traditional electrochemistry teaching (didactic lecture) and their thought on the use of GOs supported with interactive PowerPoint presentation technology in the teaching electrochemistry were considered. Secondly, the study investigated the learning experience and views of the PCTs in the second study group who experienced GOs supported with interactive PowerPoint presentation technology in the teaching electrochemistry. Thus, taking the views of different PCT groups with different levels and different experiences enriched the findings of the study by revealing their thoughts about electrochemistry teaching from different perspectives and provided an insight into the effects of electrochemistry teaching with GOs supported with interactive PowerPoint presentation technology on learners' comprehension and motivation and how to remedy learning difficulties concerning concepts. Therefore, the results of the studies will be discussed in this section from two aspects. First of all, the experiences and views of PCTs about the course where electrochemistry teaching is carried out with traditional methods, that is, teaching is based only on verbal explanations, PowerPoint slides are used only for the presentation of written materials, and plenty of algorithmic question solutions will be included. On the aspect of GOs supported with interactive PowerPoint presentation technology in the teaching electrochemistry, the conclusions reached about the common points of all PCTs will be discussed secondly.

The PCTs in the first group were the group that experienced electrochemistry learning in an environment where electrochemistry was taught using a traditional method (didactic lecture). When the findings of the learning experiences of PCTs in this group were examined, it was determined that all of them emphasized that it was not easy to learn the subjects and concepts of electrochemistry and that they had difficulties while learning the subjects of electrochemistry. It was concluded that they stated that they had difficulties especially with anode/cathode, redox, and electrochemical cells. An important reason for this was stated that only the didactic way of presentation of electrochemistry subjects was used in teaching, and therefore it was determined that they could not get the efficiency they wanted from the course. They stated that the learning of the concepts was not emphasized and more problem solving was done, so they confused the anode/cathode concept, for example, and they could not fully understand the difference in galvanic and electrolytic cells. When the studies on electrochemistry are examined, as can be seen from the misconceptions given in Table 1, it has been revealed in many studies that students at almost all levels have problems with electrochemistry concepts. For this reason, it is seen that these experiences of the PCTs are consistent with these results determined from electrochemistry studies. In addition, studies show that the reason for learning electrochemistry subjects or misconceptions is largely related to teaching strategies (Özkaya et al., 2003). The Electrochemistry course includes intensive cognitive knowledge as well as quantitative problem-solving abilities. On the other hand, turning course content into routine algorithmic problems by teachers without requiring much conceptual knowledge has shown that it does not contribute much to students' learning. Ogude and Bradley (1996) stated that although many students can solve quantitative electrochemical problems in exams, few can answer qualitative questions that require a deeper conceptual knowledge of electrochemistry. The results of this study were determined to be consistent with this claim. Özkaya et al. (2003) reached a similar conclusion in their study in which 
they examined the conceptual difficulties of PCTs in understanding fundamental aspects of electrochemistry related to galvanic and electrolytic cells. They determined that although a significant number of PCTs are capable of solving various complex electrochemistry problems, The PCTs cannot demonstrate satisfactory knowledge of the basic concepts of electrochemistry. They stated that the electrochemistry course and exams emphasize the quantitative and mathematical aspects of the subject, and this approach teaches students to calculate by rote learning algorithms, but they do not need to construct proper meanings for the ideas involved in the calculations. They also stated that students from different countries and different levels of electrochemistry study have similar difficulties and suggest that concepts are presented to them poorly. Amponsah (2020) reached similar results for South African twelfth-grade students and found that the students essentially emphasized algorithmic issues instead of conceptions. He stated that one of the reasons for this situation may be that teachers focus more on algorithmic problems related to electrolytic cells in the classroom.

After determining the traditional electrochemistry teaching experiences of these PCTs in the first group, showing and explaining to them how to use the GOs supported with interactive PowerPoint presentation technology in the teaching electrochemistry, what they thought about this type of electrochemistry teaching was examined. From the findings related to these thoughts, it was determined that they thought that the use of the GOs supported with interactive PowerPoint presentation technology in the teaching electrochemistry would be beneficial, that it would improve the retention of information and provide a better understanding of the expressions. In addition, it was concluded that the use of GOs would attract the attention of the students and make the lesson fun, as well as express positive thoughts in the affective dimension. It was concluded that some of the PTCs who stated that they had difficulties during the teaching of the electrochemistry course, stated that if such an approach and GOs were used in their courses, they would not have experienced these difficulties and they could learn the concepts of electrochemistry better and easily. It was determined that the suggestions made by Ozkaya et al (2003) in order to provide deep conceptual teaching about electrochemistry and to prevent misunderstandings overlap with the thoughts of the PCTs in the first group of our study. They pointed out that when various concepts about cells are taught in isolation from each other, they cannot be understood and therefore a teaching strategy where the cell can be understood in its entirety should be adopted to eliminate misconceptions about these concepts. They emphasized that an effective teaching strategy aimed at improving students' understanding of galvanic and electrolytic cells should also take into account the documented misconceptions about electrochemistry, their likely origins, and suggestions of previous studies concerning overcoming these misconceptions. Besides, when the studies determined that teaching electrochemistry with different methods affects the students' conceptual understanding are examined (Ahmad et al, 2021; Al-Balushi et al., 2017; Iksan \& Daniel, 2015; Osman \& Lee, 2014; Prihastyanti et al., 2020), the common point in all of them is that they have a similar perspective in which they promote active learning strategies.

Another conclusion of this study was related to the views of all PCTs for the use of the GOs supported with interactive PowerPoint presentation technology in teaching electrochemistry. The results obtained from the findings of all PCTs participating in the study related to this situation in the study were turned into a graphical representation as shown in Figure 4.

As seen in Figure 4, the views of the PCTs concerning the use of the GOs supported with interactive PowerPoint presentation technology in teaching electrochemistry concepts are collected in two main groups. These are the contributions of the use of GOs to the teaching process and the effects on the misconceptions. The findings indicated that the positive contribution of the use of GOs to the electrochemistry teaching process was approached by the PCTs in two ways that we can remark as cognitive and affective. While the views about the cognitive domain are labeled as "enhanced students' comprehension", the views about the affective domain were labeled as "enhanced students' motivations".

Regarding the PCTs' views of enhanced students' comprehension, it was determined that all PCTs in both study groups put forth views on this issue and these views were positive. Similarly, GilGarcia and Villegas (2003) revealed that faculty members thought GOs to be valuable teaching tools, and they acknowledged the value of GOs in helping teacher candidates develop higherlevel critical thinking skills. Cala (2019) found that the outperformance of the experimental group was due to the use of graphic organizers integrated into lesson packages. Cala (2019) was also determined that students thought that GOs help them understand scientific concepts easily, make the topic more understandable, provide more information, and easily memorize the concepts. Gallavan and Kottler (2007) also concluded that the GOs allow teachers and students to summarize and evaluate information into visual models that can be used quickly and easily, and also help students record and recall information.

Regarding the PCTs' views of the affective domain, it was determined that some of the PCTs indicated that the GOs were attractive and the use of GOs increased their focus on the lessons and made the lesson fun. The present study supports previous studies' findings. For example, Gallavan and Kottler (2007) found that GOs make learning manageable and fun. As in the study of Gallavan, and Kottler (2007), in some studies, it is seen that students present cognitive views about the use of GOs as well as views about the effect on the affective domain. Torres, España, and Orleans, (2014) have also reached similar results concerning the affective domain results of this study. They determined that facilitating the learning environment with the integration of graphic organizers (GOs) as a learning tool in selected topics in chemistry helped students' attitudes towards chemistry lessons improve and students' perceptions were good. 


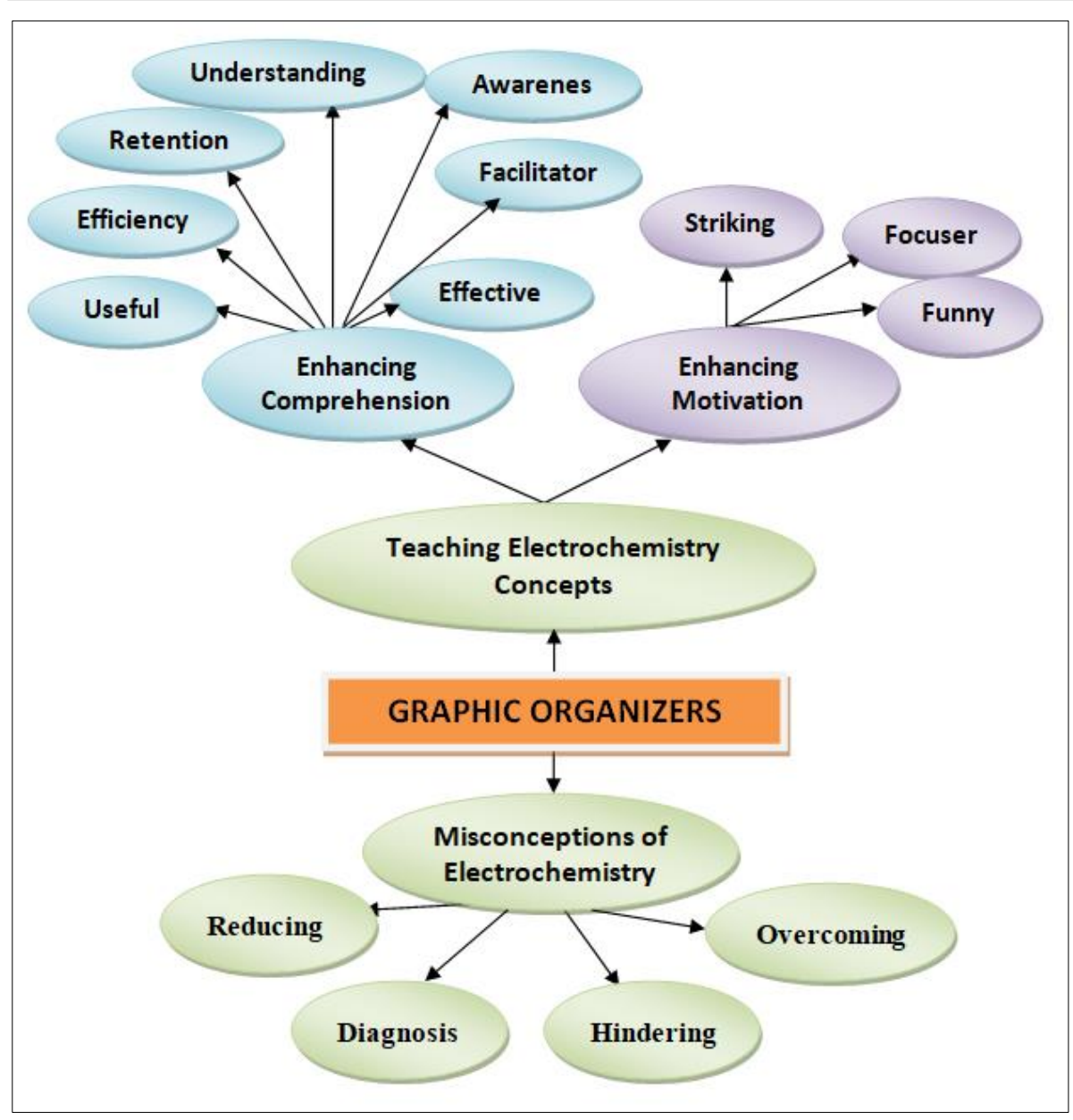

Figure 4. A graphical representation of the views of PCTs concerning the use of the GOs supported with interactive PowerPoint presentation technology in teaching electrochemistry

Another considerable conclusion of the present study is the results related to the PCTs' thoughts on the effects on the students' misconceptions concerning electrochemistry. It is revealed that the PCTs thought that the use of GOs affected overcoming, preventing, diagnosing, and reducing misconceptions concerning electrochemistry. The present study concerning this issue is consistent with the study of Gil-Garcia and Villegas (2003). They determined that students thought that GOs were essential to cleaning up misconceptions about topics we were studying. Gil-Garcia and Villegas (2003) also revealed that students considered the GOs helped them to organize their thoughts, and to understand complicated ideas easily. The examples given by PCTs in their explanations about misconceptions of electrochemistry are also remarkable. They drew attention to the problems with the salt bridge and it was stated that it would provide a better understanding of the GO salt bridge used. Learning difficulties regarding the salt bridge are one of the important problems identified by many researchers in the electrochemistry literature (Allsop \&George, 1982; Garnet \& Treagust, 1992; Ogude \& Bradley, 1994; Sanger \& Greenbowe, 1997).

\section{Limitations}

This study has several limitations. The chief limitation of the study is the small sample size and those PCTs participating in the study may not have been a representative sample of all PCTs. No experimental study including experimental and control group comparison has been done in the present study and this may have hindered our ability to detect differences between groups or the effects of the use of GOs in electrochemistry teaching. In addition, student learning outcomes in this study were not assessed. However, it is important that the data were collected through interviews in the first study group, that the second group of the study was taught about GOs by one of the authors, and that the authors had the opportunity to directly observe the use of GOs. Besides, although the focus of the research and the quality of the research questions are decisive in the selection of the phenomenology design, the fact that data was collected through semistructured interviews only in the first group can be considered as a limitation. When the study findings are evaluated from this perspective, it seems to have the potential to serve as a pioneering study to guide future studies.

\section{Implications}

It was concluded that the PCTs have positive views like enhancing both students' comprehension and motivation about the use of GOs in teaching electrochemistry concepts in this study. Therefore, it can be suggested that the GOs should be included in teaching electrochemistry at both chemistry teacher training programs and high school chemistry lessons. For this purpose, different types of GOs for both university and high school levels can be prepared by the expert chemistry educators for the chemistry subjects and concepts that students have difficulty understanding or hold misconceptions about and can be shared with chemistry instructors and high school chemistry teachers.

Since the students' misconceptions can impede the learning process, it is essential to organize teaching in a way that prevents the development of these misconceptions or to diagnose the current misconceptions in the learning process of students and try to overcome these misconceptions with conceptual change. The GOs constructed in this study were specially prepared by taking into account the concepts of electrochemistry that students have problems with while learning. As seen the results obtained from the second study group, based on the fact that PCTs' misconceptions of electrochemistry were prevented by using the GOs in the lessons, 
it can be recommended that while preparing the GOs to be used in the lessons, the previous studies on the subject taught should be examined and it should be taken into account their results concerning problems of students' understanding or misconceptions.

Teaching electrochemistry is also challenging for many teachers, especially beginner chemistry teachers. In the present study, the PCTs have received training on how to use the GOs in the teaching of electrochemistry concepts and how to handle students' learning difficulties or misconceptions about them by using GOs. Since the implementation with using the GOs in the present study will also be a guide for the future electrochemistry lessons for the PCTs and will increase the experience, such implementation should be included in the PCTs' electrochemistry courses.

In the teaching approach used in this study, the use of partial and complete GOs was preferred. It has been determined in the literature that the use of partial GO and they are completed with the interaction during lessons contributes positively to their learning (Robinson et al., 2006). Ponce et al. (2018) determined adding the graphic organizers to an instructional slideshow would improve student engagement and generative learning as compared with a content-based instructional approach based on a slideshow without interactive graphic organizers. Based on these results, the GOs supported with interactive PowerPoint presentation technology can be suggested to use in teaching chemistry concepts.

In the introductory part of the study, it was stated that although this study was not conducted in an online teaching process, several implications regarding the use of GOs in online courses will be discussed based on the results of this study. Therefore, a final suggestion regarding the use of GOs in online courses is included here. The two most important challenges in online courses are to increase the motivation of students and to provide their cognitive engagement participation in the lesson. Both of these challenges can be achieved by activating students in the lesson. The most important activity that can be done for students' cognitive participation is to provide a discussion environment and to engage them in collaborative online discussions. Kwon et al. (2018) have indicated that using a GO in online discussions can be advantageous in online discussions than participating in a discussion in the forum in a typical online thread. Because a GO can visualize selected issues and their relations so that students can efficiently grab the relations of arguments. To create an active discussion environment in online chemistry lessons, it may be suggested to include GOs in the teaching sequences. Besides, a similar teaching approach presented in this study can be suggested to use in online discussion contexts and to complete the partial GOs by discussing with students during online lessons.

\section{Disclosure Statement}

The authors report no conflict of interest.

\section{References}

Aguiara, J. G., \& Correia, P. R. M. (2016). Using concept maps as instructional materials to foster the understanding of the atomic model and matter-energy interaction. Chemistry Education Research and Practice, 17(4), 756-765.

Ahmad, N. J., Yakob, N., Bunyamin, M. A. H., Winarno, N., Akmal, W. H. (2021). The effect of interactive computer animation and simulation on students' achievement and motivation in learning electrochemistry. Jurnal Pendidikan IP A Indonesia, 10 (3), 311-324.

Allsop, R. T., \& George, N. H. (1982). Redox in Nuffield advanced chemistry. Education in Chemistry, 19, 57-59.

Alvermann, D. N., \& Boothby, P. R. (1986). Children's transfer of graphic organizer instruction. Reading Psychology, 7(2), 87-100.

Amponsah, K. D. (2020). South African twelfth grade students' conceptions regarding Electrochemistry. Journal of Education and Learning (EduLearn), 14(3), 362-368.

Anders, P. L., \& Bos, C. S. (1986). Semantic Feature Analysis: An interactive strategy for vocabulary development and text comprehension. Journal of Reading, 29(7), 610-616.

Brandriet, A. R., \& Bretz, S. L. (2014). Measuring meta-ignorance through the lens of confidence: examining students' redox misconceptions about oxidation numbers, charge, and electron transfer. Chemistry Education Research and Practice, 15, 729-746.

Butts, B., \& Smith, R. (1987). HSC chemistry students' understanding of the structure and properties of molecular and ionic compounds. Research in Science Education, 17, 192-201.

Cala, R. F. (2019). Integrating graphic organizers in lesson packages and its effect to students' levels of conceptual understanding. International Journal of Secondary Education, 7(4), 89-100.

Cheung, D. (2011). Using diagnostic assessment to help teachers understand the chemistry of the lead-acid battery. Chemistry Education Research and Practice, 12(2), 228-237.

Chandler, P., \& Sweller, J. (1991). Cognitive load theory and the format of instruction. Cognition and Instruction, 8 $293-332$.

Chamizo, J.A. (2012). Heuristic Diagrams as a Tool to Teach History of Science. Science \& Education, 21, 745-762 (2012).

Cofer, K. (2021). The efficacy of graphic organizers in an inner-city high school self-contained chemistry classroom for students with disabilities. Unpublished Master of Education Thesis, William Paterson University of for students

Creswell, J. W. (2007). Qualitative inquiry and research design: Choosing among five approaches I John W. Creswell-2nd ed, Sage Publications, Inc.

Davidowitz, B., \& Rollnick, M. (2001). Effectiveness of flow diagrams as a strategy for learning in laboratories. Australian Journal of Education in Chemistry, 57, 18-24.

De Jong, O., \& Treagust, D. (2003). The teaching and learning of electrochemistry. In J.K. Gilbert et al. (Eds.), Chemical education: Towards research-based practice, (pp. 317-337). Netherlands: Kluwer Academic Publishers.

DeMeo, S. (2007). Constructing a graphic organizer in the classroom: introductory students' perception of achievement using a decision map to solve aqueous acid-base equilibria problems. Journal of Chemical Education, 84(3), 540-546.

Dye, G. A. (2000). Graphic organizers to the rescue! Helping students link and remember information. Teaching Exceptional Children, 32(3), 72-76.

Ellis, E., \& Howard, P. (2007). Graphic organizers: Power tools for teaching students with learning disabilities. Current Practice Alerts, 13,1-4.

Ezeh, D. N., \& Okeke, O. J. (2018). Effect of mend mapping teaching strategy (MMTS) on chemistry students' achievement, interest, and retention in Enugu. International Journal of Research in Medical and Basic Sciences, $4(11), 48-70$. 
Ezzeldin, S. M.Y. (2017). The effectiveness of using graphic organizers in development of achievement, reduction of cognitive load associated with solving algorithm problems in analytical chemistry and favored learning styles among female secondary school students in Saudi Arabia. International Journal for Research in Education, $41(2), 77-124$.

Foley, K., \& O'Donnell, A. (2002). Cooperative learning and visual organisers: effects on solving mole problems in high school chemistry. Asia Pacific Journal of Education, 22(1), 38-50.

Fitzgerald, W. J., Elmore, J., Kung, M., \& Stenner, A. J. (2017). The conceptual complexity of vocabulary in elementary-grades core science program textbooks. Reading Research Quarterly, 52(4), 417-442.

Frayer, D., Frederick, W. C., \& Klausmeier, H. J. (1969). A schema for testing the level of cognitive mastery. Madison: Wisconsin Center for Educational Research

Gallavan, N. P., \& Kottler, E. (2007). Eight types of graphic organizers for empowering social studies students and teachers. The Social Studies, 98(3), 117-128.

Garnet, P. J., \& Treagust, D. F. (1992a). Conceptual difficulties experienced by senior high school students of electrochemistry: Electrochemical (Galvanic) and electrolytic cells. Journal of Research in Science Teaching, 29(10), 1079-1099.

Garnet, P. J., \& Treagust, D. F. (1992b). Conceptual difficulties experienced by senior high school students of electrochemistry: Electric circuits and oxidation-reduction equations. Journal of Research in Science Teaching, 29(2), 121-142.

Gay, L. R., \& Airasion, P. (2000). Educational research: Competencies for analysis and application. New Jersey: Prentice-Hall.

Ghirardi, G., Marchetti, F., Pettinari, C., Regis, A., \& Roletto, E. (2014). A teaching sequence for learning the concept of chemical equilibrium in secondary school education. Journal of Chemical Education, 91(1), 59-65.

Gil-Garcia, A., \& Villegas, J. (2003). Engaging minds, enhancing comprehension and constructing knowledge through visual representations. Paper presented at the Conference on Word Association for Case Method Research and Application, Bordeaux, France.

Giorgi, A. (1992). Description versus Interpretation: Competing Alternative Strategies for Qualitative Research. Journal of Phenomenological Psychology, 23(2), 119-135.

Habiddin, H., \& Page, E.M. (2021). Examining students' ability to solve algorithmic and pictorial style questions in chemical kinetics. International Journal of Science and Mathematics Education, 19, 65-85.

Horton, S. V., Lovitt, T. C., \& Bergerud, D. (1990). The effectiveness of graphic organizers for three classifications of secondary students in content area classes. Journal of Learning Disabilities, 23(1), 12-22.

Isabirye, A. K. \& Makoe, M. (2018) Phenomenological Analysis of the Lived Experiences of Academics who Participated in the Professional Development Programme at an Open Distance Learning (ODL) University in South Africa, Indo-Pacific Journal of Phenomenology, 18(1), 29-39.

Iksan, Z. H., \& Daniel, E. (2015). Emerging model of questioning through the process of teaching and learning electrochemistry. International Education Studies, 8(10), 137-149

Johnstone, A. H. (1997). Chemistry teaching, science or alchemy? Journal of Chemical Education, 74, 262-8.

Kong, Y. T. (2016). An analysis of the recognition on definition and mechanism of electrolysis for university students major in science education. International Journal of Applied Chemistry, 12(3), 463-481.

Kumar R. (1999). Research methodology: a step by step guide for beginners, Sage Publications, 2nd ed.

Kummari, V. (2017). To what extent do graphic organizers influence the academic achievement of ninth-grade chemistry students? A professional paper submitted in partial fulfillment of the requirements for the degree of Master of Science in Science Education, Montana State University. Retrieved from https://scholarworks.montana.edu/xmlui/bitstream/handle/1/13674/KummariV0817.pdf?sequence $=5$, 21.11.2021.
Kwon, K., Shin, S., \& Park, S. J. (2018). Effects of graphic organizers in online discussions: comparison between instructor-provided and student-generated. Educational Technology Research and Development, 66, 1479-1503

Lu, S., \& Bi, H. (2016). Development of a measurement instrument to assess students' electrolyte conceptual understanding. Chemistry Education Research and Practice, 17(4), 1030-1040.

Maziadi, H. A. (2018). Impact of visual graphic organizer in the study of information action research. Journal of Education and Practice, 9(3), 5-17.

Mayer, R. E., \& Moreno, R. (2003). Nine ways to reduce cognitive load in multimedia learning. Educational Psychologist, $38,43-52$.

McKnight, K. S. (2010). The teacher's big book of graphic organizer, San Francisco: Jossey Bass.

Moyses, D. D., Rivet, J. L., \&. Fahlman, B. D. (2010). Using concept maps to teach a nanotechnology survey short course. Journal of Chemical Education, 87(3), 285-290.

Nakhleh, M. B. (1992). Why some students don't learn chemistry. Journal of Chemical Education, 69(3), 191- 196.

Nakiboğlu, C. (2003), Instructional misconceptions of Turkish prospective chemistry teachers about atomic orbitals and hybridisation, Chemistry Education Research and Practice, 4, 171-188.

Nakiboğlu, C. (2008), Using word associations for assessing nonmajor science students' knowledge structure before and after general chemistry instruction: the case of atomic structure. Chemistry Education Research and Practice, $9(4), 309-322$.

Nakiboğlu, C., \& Ertem, H. (2010). Atom ile ilgili kavram haritalarının yapısal, ilişkisel ve öneri doğruluğu puanlaması analiz sonuçlarının kıyaslanması. Türk Fen Ë̆itimi Dergisi, 7(3), 60-77.

Nakiboğlu, C., \& Yıldırır, H. E. (2011), Analysis of Turkish high school chemistry textbooks and teacher-generated questions about gas laws. International Journal of Science and Mathematics Education, 9, 1047-1071.

Nakiboğlu, C., Șen, A. Z., Akgün, İ., \& Fidan, M. (2016). Genel Kimya laboratuarında akış diyagramı kullanımına yönelik öğretmen adaylarının görüşlerinin incelenmesi. Journal of the Turkish Chemical Society-C: Chemistry Education, 1(1), 63-86.

Nakiboğlu, N., \& Nakiboğlu, C. (2017a), Kimya öğretmen adaylarinin elektrokimya kavramlarını anlama düzeylerinin incelenmesi, In N. Akpinar Dellal ve S. Tican Başaran (Ed.), Uluslararası Çağdaş Eğitim Araștırmaları Kongresi Bildiri Özetleri Kitabi (pp. 108). Ankara: Anı Yayınclık Eğitim ve Danıșmanlık San. Tic. Ltd. Şti.

Nakiboğlu, N., \& Nakiboğlu, C. (2017b), Investigation of high school students' understanding about electrochemistry concepts. Paper presented at the International Conference on Education in Mathematics, Science \& Technology, Kusadasi/Turkey.

Nakiboğlu, N., \& Nakiboğlu, C. (2018), Examination of 12th Grade Students' Cognitive Structures about Electrochemical Concepts through Word Association Test, In H. Arslan et al. (eds.), Educational Policy and Research, (pp 293-300). Kraków: Jagiellonian University Institute of Public Affairs.

Nakiboğlu, N., \& Nakiboğlu, C. (2016). An investigation of university chemistry students' understanding of precipitation titrations and related concepts thorough Vee-diagrams. The Eurasia Proceedings of Educational and Social Sciences, 4, 564-567

Nakiboğlu, N. \& Nakiboğlu, C. (2017c). University chemistry students' views about use of vee-diagram in analytical chemistry laboratory. In International Symposium on Philosophy, Education, Arts and History of Science, pp. 246-526. Mayıs, 2017, Muğla.

Nakiboğlu, C. (2017). Use of Graphic Organizers Secondary Chemistry Lessons. The Eurasia Proceedings of Educational and Social Sciences, 7, 72-75. Retrieved from https://dergipark.org.tr/en/pub/epess/issue/30770/332658

Nakiboğlu, N, Filiz, F., \& Nakiboğlu, C. (2017). Investigation of university chemistry students' views about flow diagram usage in analytical chemistry laboratory I. International Conference on Education in Mathematics, Science \& Technology (ICEMST), Ephesus-Kusadasi/Turkey, 268-272. 
Nakiboğlu, C., Erdurmazlı, İ, Kızmaz, B., Hepöz, Ş. (2018) Kimya Öğretmen Adaylarının Organik Kimya Laboratuarında Akış Diyagramı Kullanımına Yönelik Görüşlerinin Araşıtırlması. Journal of the Turkish Chemical Society-C: Chemistry Education, 3(1), 31-58.

Nakiboğlu, C., \& Nakiboğlu, N. (2019). Exploring prospective chemistry teachers' perceptions of precipitation, conception of precipitation reactions and visualization of the sub-microscopic level of precipitation reactions. Chemistry Education Research and Practice, 20(4), 873-889.

Nengsi, A. F., \& Narius, D. (2016). Increasing students' vocabulary mastery by using concept definttion map strategy through reading activity to junior high school students. Journal of English Language Teaching, 5(1) 112-119.

Nurrenbern, S. C., \& Pickering, M. (1987). Concept learning versus problem solving: Is there a difference? Journal of Chemical Education, 64(6), 508-510.

Nyachwaya J. M., Mohamed A-R., Roehrig G. H., Wood N. B., Kern A. L., \& Schneider J. L. (2011). The development of an open-ended drawing tool: an alternative diagnostic tool for assessing students' understanding of the particulate nature of matter. Chemistry Education Research and Practice, 12, 121-132.

Nyachwaya, J. M., Warfa, A. R. M., Roehrig, G. H., \& Schneider, J. L. (2014). College chemistry students' use of memorized algorithms in chemical reactions. Chemistry Education Research and Practice, 15(1), 81-93.

Nyagblormase, G. A., Gyampoh, A. O., Hinson, J., Aidoo, B., \& Yeboah, E. (2021). Effect of mind mapping as a learning tool on online learning of chemistry. Studies in Learning and Teaching, 2(2), 47-58.

Ogude, A.N., Bradley, J. D. (1994). Ionic conduction and electrical neutrality in operating electrochemical cells: precollege and college student interpretations. Journal of Chemical Education, 71(1), 29-34.

Ogude, A.N., \& Bradley, J. D. (1996). Electrode processes and aspects relating to cell emf, current, and cell components in operating electrochemical cells: Precollege and college student interpretation. Journal of components in operating electroch
Chemical Education, 73(12), 1145-49.

Osman, K., \& Lee, T. T. (2014). Impact of interactive multimedia module with pedagogical agents on students understanding and motivation in the learning of electrochemistry. International Journal of Science and Mathematics Education, 12(2), 395-421.

Özkaya, A. R. (2002). Conceptual difficulties experienced by prospective teachers in electrochemistry: Half-cell potential, cell potential, and chemical and electrochemical equilibrium in galvanic cells. Journal of Chemical potential, cell potential,
Education, $79(6), 735-738$.

Özkaya, A. R., Üce, M., \& Şahin, M. (2003). Prospective teachers' conceptual understanding of electrochemistry: Galvanic and electrolytic cells. University Chemistry Education, 7, 1- 12.

Papaphotis, G., \& Tsaparlis, G. (2008). Conceptual versus algorithmic learning in high school chemistry: The case of basic quantum chemical concepts, Part 2. Students' common errors, misconceptions and difficulties in understanding. Chemistry Education Research and Practice, 9, 332-340.

Patton, M. (2002). Qualitative Research and Evaluation Methods, Thousand Oaks, CA: Sage, 3rd Edn.

Phelps, A. J. (1996). Teaching to enhance problem solving: it's more than the numbers. Journal of Chemical Education, 73(4), 301.

Phillips, K. L. (1989). Relating the Mole Concept and Fundamental Mathematics. ERIC Document, ED 325392.

Pickering, M. (1990). Further studies on concept learning versus problem solving: Is there a difference? Journal of Chemical Education, 67, 254-255.

Polancos, D. T. (2013). Effects of Vee diagram and concept mapping on the achievement of students in chemistry. Liceo Journal Higher Education Research, 7(1), 160.

Ponce, H. R., Mayer, R. E., López, M. J., \& Loyola, M. S. (2018). Adding interactive graphic organizers to a wholeclass slideshow lesson. Instructional Scence, 46, 973-988.

Prihastyanti, N., Rokhim, D. A., Subandi, S., \& Sigit, D. (2020). Development of contextual teaching and learning (CTL) based learning materials to facilitate students in improving critical thinking ability in redox and (CTL) based learning materials to facilitate students in im
Rahayu, S., Treagust, D. F., Chandrasegaran, A.L, Kita, M., \& Ibnu, S. (2011). Assessment of electrochemical concepts: a comparative study involving senior high-school students in Indonesia and Japan. Research in Science \& Technology Education, 29(2). 169-188.

Rahayu, S., Treagust, D. F., \& Chandrasegaran, A. L. (2021). High School and Preservice Chemistry Teacher Education Students' Understanding of Voltaic and Electrolytic Cell Concepts: Evidence of Consistent Learning Difficulties across Years. International Journal of Science and Mathematics Education, 1-24, https://doi.org/10.1007/s10763-021-10226-6.

Raymond, T. M. F., Khang, G. N., \& Sai, C. L. (2001). Some thoughts on designing multimedia courseware as a tool for enhancing process and thinking skills in chemical education. Teaching and Learning, 22(1), 74-83.

Robinson, D. H., Katayama, A. D., Beth, A., Odom, S., Hsieh, Y., \& Vanderveen, A. (2006). Increasing text comprehension and graphic note taking using a partial graphic organizer. The Journal of Educational Research, 100, 103-111.

Robinson, D. H., Katayama, A. D., Dubois, N. F., \& Devaney, T. (1998). Interactive effects of graphic organizers and delayed review on concept application. The Journal of Experimental Education, 67(1), 17-31.

Sanger, M. J., \& Greenbowe, T. J. (1997a). Students' misconceptions in electrochemistry: Current flow in electrolyte solutions and the salt bridge. Journal of Chemical Education, 74(7), 819-823.

Sanger, M. J., \& Greenbowe, I. J. (1997b). Common students' misconceptions in electrochemistry: Galvanic, electrolytic and concentration cells. Journal of Researcb in Science Teacbing, 34(4), 377-398.

Schwartz, R. M., \& Raphael, T. E. (1985). Concept of definition: A key to improving students' vocabulary. The Reading Teacher, 39(2), 198-205.

Singh, I. S., \& Moono, K. (2015). The effect of using concept maps on student achievement in selected topics in chemistry at tertiary level. Journal of Education and Practice, 6(15), 106-116.

Stahl, S. A. (1986). Three principles of effective vocabulary instruction. Journal of Reading, 29(7), 662-668.

Stahl, S. A. (1985). To teach a word well: A framework for vocabulary instruction. Reading World, 24(3), 16-27. doi:10.1080/19388078509557828

Stull, A. T., \& Mayer, R. E. (2007). Learning by doing versus learning by viewing: Three experimental comparisons of learner-generated versus author-provided graphic organizers. Journal of Educational Psychology, 99(4), 808820.

Taber, K.S. (1994). Misunderstanding the ionic bond. Education in Chemistry, 31(4), 100-103.

Taber, K.S, Tsaparlis, G. (2012). Student conceptions of ionic bonding: Patterns of thinking across three European contexts. International Journal of Science Education, 34(18), 2843-2873.

Torres, M. O., España, R. C. N., \& Orleans, A. V. (2014). Integrating graphic organizers in facilitating learning chemistry. International Journal of Educational Studies, 1(1), 1-8

Virk, J., \& Wik, H. (2011). Graphic Organizers: Cognitive Origins, Constructivist Implications. Retrieved from http://etec.ctlt.ubc.ca/510wiki/Graphic Organizers: Cognitive Origins, Constructivist Implications

Wills, S., \& Ellis, E. (2008). Theoretical and Empirical Basis for Graphic Organizer Instruction, Retrieved February 12, 2021, from http://docplaver.net/25253424-The-theoretical-and-empirical-basis-for-graphicorganizerinstruction.html

Weinstein, C. E., \& Mayer, R. E. (1986). The teaching of learning strategies. In M. C. Wittrock (Ed.), Handbook of research on teaching (pp. 315-327). New York: Macmillan

Yang, E. M., Greenbowe, T. J., \& Andre, T. (2004). The effective use of an interactive software program to reduce students' misconceptions about batteries. Journal of Chemical Education, 81(4), 587-595. 